\title{
Balinese Literature Works Sourcing On Jaya Kuna Literature: Case Genre Geguritan
}

\author{
Luh Putu Puspawati ${ }^{*}$, I Made Suastika ${ }^{2}$ \\ ${ }^{1}$ FIB Unud \\ \{luhputupuspawati@gmail.com $\left.{ }^{1}\right\}$
}

\begin{abstract}
A number of Balinese literary works with the geguritan genre have emerged in the history of Balinese literary works. The emergence of literature in Bali with the genre of geguritan, some directly took the theme of Balinese nature, but most of them took Old Javanese literature as their source (babon), then adapted it according to the Balinese literary genre at that time. The existence of this phenomenon, the aim of the study traces the geguritan texts that originate from the Old Javanese epic literature in the Balinese Mahabharata and Kakawin Ramayana, which is called pem-Balian. The method of the research was based on the research from text and field research. Thus, the results show that the existence of Balian serves to transmit the values in Old Javanese texts into the Balinese tradition by incorporating elements of Balinese language, literature and culture, dynamically as an orthogenetic, namely changing intrinsic texts continuously according to developments in the world of politics, history, literature, and Balinese people.
\end{abstract}

Keywords: Ramayana; Mahabharata; geguritan; pem-Balian

\section{Introduction}

In the field of Balinese literature and culture, it has long received elements of Old Javanese from the aspects of language, literature and culture. Then these elements are not re-adjusted to the values of Balinese culture, so that literary works that are born as new creations continue the Old Javanese values in addition to the transformation in a new model.

The Balian process in Bali took place for a long time, starting in the Gelgel and Klungkung era (16-19 centuries) and even today. The technique is carried out by taking baboons (source text) of Old Javanese Literature and then transforming them into new stories and even changing genres, new characters, and using the Balinese language from the source, Old Javanese Language. The Balinese literary works that appear with this Balinese literature are felt to be the milk of the community in the text of the Balinese cultural era.

In the case of pem-Balian, this research examines the work of geguritan in Bali which originates from the Mahabharata epic and the Ramayana epic. 


\section{Method}

This research data from text and field research. Data collection, observation methods to observe and search for texts and manuscripts in text fields, such as in Gedong Kertya Singaraja, a lontar institute at the Faculty of Cultural Sciences, Udayana University. Balinese cultural documentation center. Then, after finding the text you are looking for, it is recorded, transliterated and translated. Same is the case with geguritan text. Interview method with informants such as classical literary figures in Bali. The library method is research in the library to find data. Then the collected data were verified, the data used were analyzed, and the results were written in the form of a paper.

The theories used are structural theory and intertextual theory. Structural theory examines the structure of the text and intertextual studies the process of balancing the two texts.

\section{Results and Discussion}

\subsection{Geguritan literary works sourced from the Mahabharata Epic}

\subsubsection{Geguritan Sarpayajnya}

The author of Kapiparwa geguritan wants to instill characters and values of morality, courage or heroism, loyalty, honesty, the law of cause and effect or karmaphala, so he looks for a parent or story model that contains these themes. Furthermore, the author makes it happen according to the genre of work that he wants, in this case his Sarpayaj geguritan.

The author of his Sarpayaj geguritan takes the essence of the story from the Old Javanese Mahabharata epic in the form of parwa (Old Javanese prose). From the parwa form, the contents of the story are explored and then poured into the form of Balinese literary works in the form of classical Balinese poetry (geguritan). The essence of the story in the Adiparwa source story (Mahabharata section) is maintained until the story ends and this will appear in the story line.

\subsubsection{Language Code in Geguritan Sarpayajnya}

Geguritan literary works generally use Balinese. But in the Sarpayajnya geguritan this is not entirely the case. There is a mix of vocabulary from Old Javanese. Balinese is one of the many languages in the archipelago and has different levels of language. The language used in its Sarpayaj geguritan includes Balinese mixed with Old Javanese.

\subsubsection{Literary Code in Geguritan Sarpayajnya}

Geguntan Sarpayajnya which was found and stored in Bali as stated above No. IVD / 10 is a Balinese literary work in the form of a tembang (pupuh). There are four (4) pupuhs used in its Sarpayaj geguritan, namely; (1) Pupuh Dangdang Guia, (2) Pupuh Pangkur, (3) Pupuh Sinom, and (4) Pupuh Durma.

\subsubsection{Flow of Geguritan Sarpayajnya}

The Srenggi son of Bhagawan Samiti and Lord Krishna were traveling to heaven. With his supernatural powers he cursed the king of Pariksit within seven days so that the Dragon Taksaka would peck him. The Srenggi immediately arrived at a hermitage in the forest and found his father still wearing a snake that was rotten. He told his father that he had cursed the king. Bhagawan Samiti regretted the curse of Sang Srenggi, especially because Sang Pariksit was his lord king who controlled the Hastinapura area. The curse of Sang Srenggi has already been spoken and cannot be withdrawn.

Naga Taksaka who received the order and Sang Srenggi to kill King Pariksit found it difficult. He then asked for help from his relatives who live in Saprapatala. His brother 
disguised himself as a priest who brought out guava fruit. The dragon Taksaka turns into a caterpillar as small as a chicken louse hiding at the tip of the guava. After the guava fruit was taken by the king, the small caterpillar turned into a dragon and immediately bit King Pariksit so that it was burned to death.

King Janamejaya, the son of Sang Pariksit, learned about this, with the help of the priests, performed a snake sacrifice ceremony (sarpayajnya). The sacrifice was intended so that the Naga Taksaka who killed his father could be burned to death during the sacrifice.

Judging from the source of the adiparwa episode in the Mahabharata section, the geguritan sarpayaj line is taken from the Maharaja Pariksit story which is in a similar plot. (Zoetmulder. 1994: 85-92)

\subsubsection{Cultural Code}

Geguritan Sarpayajnya also functions to play (the continuation of Ngaben) according to its form, namely the song is an entertainment that gives a sense of calm, reduces fatigue and fatigue. In terms of its function as entertainment, his verses were developed in various performing arts such as arja, wayang, and ballet.

The culture to always self-reflect is also contained in his Sarpayaj geguritan. One should always be calm, not quick to get angry, like Sang Pariksit, who did not receive an answer from Bhagavan Samiti who was monabratha (silent). The educational element is also contained in it, especially religious education related to the law of karmaphala (results of actions).

\subsection{Creation of Kicaka Geguritan}

Initially the writer apologized because the writer made the song with the song (puh) dangdang, the voice was a bit messy because the writer called himself humbly. Then the author makes a literary work in the form of a geguritan story about Kicaka with the intention of fulfilling Dayu Byang Sloka's request, who at that time asked to make a song (kidung) with pupuh dangdang, by taking the story of the Pandavas and his wife serving in the kingdom of Wirata (Mahabharata section).

\subsubsection{Language Code}

The language relationship between Wirataparwa (Mahabharata) and Geguritan Kicaka shows the use of a different language, namely in the form of balian as a process of using Balinese in literary works previously written in Old Javanese. Here it is clear that the Balinese language entered as a means of communication in literature.

\subsubsection{Literary Code}

The Pandavas disguised themselves in the Wirata kingdom for one year. Here the Pandavas change themselves with their respective names. They disguise themselves by removing their oversized clothes and wearing normal clothes. The death of Patih Kicaka who initially seduced Dewi Sairindri, he was killed by Sang Ballawa. Death was heard in Trigarta, the vassal kingdom of Wirata and the kingdom united with the Kauravas to invade Wirata. The war broke out, King Matsya ordered Kangka, Ballawa, Grantika, Tantipala against the Korawa and Trigarta troops. Wrhatnala became a train driver for Rajaputra.

On the way Wrhatanala changed positions, he became the leader of the war and Uttara became the coachman and took clothes stored in the cave. The Korawa troops lost. King Matsya was delighted to hear that his son had won and would return to the palace. There was a misunderstanding about the hero who won, then Panca Pandavas came to the palace to reveal his true self. He refused the gold and wealth to be handed over to the Pandavas, but one that was accepted was Dewi Uttari, who was married to Arjuna's son Abhimanyu.

\subsubsection{Cultural Code}


The broader understanding of this literary work is in the context of the freedom of art in Bali, that literary works remain alive because of the appreciation of the value of literary works. For example, Wirataparwa is sung in phalawakya and used in wayang plays, ballet, semi-painting, ornate sculptures (ornament) both in houses and on temple walls in Bali. These are forms of Wirataparwa's cultivation, so that the work remains alive in society through various understandings in the aspects of Balinese language, literature and culture.

The loyalty of Dewi Drupadi (Sairindri) following her husband to evacuate to Wirata, as a model of how loyal a wife is to her husband (alaki-rabi).

\subsection{Geguritan literary works from the Kakawin Ramayana}

The author of Geguriran Kapiparwa I Made Bija also mentions that in brackets (Ramayana) it clearly means that the Kapiparwa text is equated with Ramayana, Kapiparwa text quotes: wenten kacarita literature, kapiparwane punika iket, high ring tembang pangkur anggen manyapuh addictive, bas kalintang, malawigkna ne nglipat, nawi dados paripurua, parisuda ban magending.

Meaning: there is a story about being told that Kapiparwa was compiled (tied up), in the tembang pangkur, used to erase desire (intention), overstepped (exaggerated), overwhelmed by eyes and obstacles (disaster), in order to be perfect, purified by singing (singing). The writer Geguritan Kapiparwa wants to rid himself of malawighua (danger) and become a saint by making songs (singing).

\subsubsection{Forms of Kakawin Ramayana and Geguritan Kapiparwa}

The Kakawin Ramayana uses the Indian model kakawin metrum form. A meter is bound by the rules of the meter. Example of Kakawin Ralnayana sargah 2 using the Basantatilika meter with the composition - - - / - - / - - / - - / - -

\subsubsection{Form of Geguritau Kapiparwa}

Geguritan Kicaka uses a pupuh / tembang tied by a lingsa, the number of lines, the number of syllables, and the ending sound of each line. The songs used in the Kapiparwa geguritan are for example: pupuh pangkur 32 pupuh, pupuh durma 28 pupuh, pupuh sinom 51 pupuh, and pupuh pangkur 52 pupuh.

\subsubsection{Language in the Kakawin Ramayana}

Kakawin Ramayana (Zoetmuder, 1994, 280-281) in Old Javanese is the source of the Kapiparwa Geguritan. The language used in the Kapipawva geguritan is Balinese kapara, which is Balinese language which is commonplace or known by the Balinese as a language user.

\subsubsection{Kakawin Ramayana storyline}

The Kekawin Ramayana consists of 25 pupuh (sargah) stories from the Ayodya palace to the return of Sita from Lengka. In short, the pestle is as follows (Zoetmulder, 1994). Pupuh 1 lives in Ayodya (Raja Dasarata, pupuh 2 Rama to the forest and gets Sita, pupuh 3 of Rama's coronation (but replaced by Bharata, pupuh 26 Rama Returns to Ayodya.

\subsubsection{Flow Geguritan Kapiparwa}

In short, the plot can be conveyed such as: pupuh 1 was born Sugriwa-Dewi NaraciBagawan Gotama (his father), pupuh 2 cupu beads then became monkeys, pupuh 3 all became monkeys (Subali-Sugriwa-Anjani) the birth of anoman, pupuh 18 stories in Ayodya Sang Dasarata, Rahwana, and Kosalya (Soka Salya).

\subsubsection{Change in Storyline}

From the brief description of the story line above, it can be said that Geguritan Kapiparwa took the story idea from Kakawin Ramayana. The episodes taken as stories are pupuh 6 and 7 as the core of the story about Sang Bali and Sugriwa. 
There is another addition from the story Utara Kanda which is used to continue the story so that it still has a relationship with Kakawin Ramayana as revealed by the author of his work name Geguritan Kapiparwa (Ramayana). Actually only taking the story idea from Kakawin Ramayana, especially pupuh 6 and 7, even though the storyline has been expanded. Also took the story idea from Ketaparwa about the daitya, danawa and giants in Lengkapura. The names of patih Completeura Si Misasura, Lembusura, Si Jatisura. The birth of Dewi Tara and the gods in heaven (heaven). Additional stories are also taken from Kakawin Arjuna Wijaya in the synomic poem, the contents of the character Arjunasastrabahu fighting against the giant Rahwana. The final part of Geguritan Kapiparwa tells about the situation in Ayodyapura, Raja Dasarata and Dewi Sokasalya and some other names such as Kosalya-Dasaratha. A little mention of sumanasa (flower) in the story line of the parts of Geguritan Kapiparwa.

\section{Conclusion}

It can be concluded from the description above as follows:

1. Geguritan Sarpayajnya and Geguritan Salya are derived from the Mahabharata text. There was a change in code, language, literature and culture towards the Balinese world. From Old Javanese to Balinese, from forms (prose genre) to poetry. Change of character names, characters, storylines.

2. Kapiparwa is composed of kakawin songs composed of the song genre (Indian metrum). In terms of the flow of Kakawin Ramayana, it contains 26 sargah (stanzas) which basically contains the life of the Dasarata in Ayodya until the return of Dewi Sita to Ayodya after being kidnapped by Sang Rahwana. Geguritan Kapiparwa takes two sargahs as the core of the story, namely sarga 6 and 7 although there are additional sargahs here and there. The storyline of Geguritan kapiparwa emphasizes the Balinese and Sugriwa figures alone as Kapiraja.

\section{References}

[1] Bawa, Anak Agung Gede, 1996, Geguritan Sarpayadnya: Satu Kajian Filologi (Tesis). Bandung: Universitas Padjadjaran.

[2] Bija, I Made, 2006, Geguritan Kapipaarwa, Panakom.

[3] Covarrubias, M. 1972, Island of Bali, Kualalumpur: Oxford University Press.

[4] Hooykaas, J. 1958, The Old Javanese Ramayana An Exemplary Kakawin as to form and content, Amsterdam, NV Noodel Hollandsche Uitgevens Meatschappy.

[5] Molen, Willem van der. 2015. Ramayana, The Story of Rama in Old Javanese, Tokyo University Foreign Studies, Tokyo.

[6] Pendit, S. Nyoman, 1980, Mahabharata, Sebuah Perang Dahsyat di Medan Kuruksetra, Jakarta : Bhratara Karya Aksara.

[7] Pigeaud, 1967-1980. Literature of Java, 4 vols, The Hague; Martinus Nijhoff.

[8] Santosa, Soewita, 1980, Ramayana Kakawin, 3 Jilid; Institut of Sotheast Asian Studies, Singapore, International Academy of Indian Cultural, New Delhi. 
[9] Suastika, Made, 1997, "Calon Arang dalam Tradisi Bali", Yogyakarta : Duta Wacana, Universitas Press.dkk, 2016. "Mahabharata Sebagai Sumber Penulisan Geguritan di Bali", Denpasar, Universitas Udayana (Penelitian)

[10] Teeuw, A. 1984, Sastra dan Ilmu Sastra Pengantar Teori Sastra, Jakarta : Pustaka Jaya.

[11] Zoetmulder, P.J, 1983, Kalangwan Sastra Jawa Kuno Selayang Pandang, Terjemahan Dick Hartoko SJ. Jakarta. Jambatan. 